\title{
Adrenergic responses of baroreceptive cells in the nucleus tractus solitarii of the rat: a microiontophoretic study
}

\author{
Peter D. Feldman and Hylan C. Moises \\ Department of Physiology, University of Michtgan, Ann Arbor, MI 48109 (US A)
}

(Accepted 10 February 1987)

Key words Autonomic, Baroreceptor reflex, Blood pressure, Catecholamıne, Microiontophoresıs, Nucleus tractus solitarin, Single unit

\begin{abstract}
Anatomical and pharmacological evidence suggests a role for catecholamines (CAs) in the modulation of the baroreceptor reflex within the nucleus tractus solitarn (NTS) Single neurons in the NTS of the rat were studied for their responses to activation of the baroreceptor reflex and to iontophoretic administration of dopamine, norepinephrine (NE), and epinephrine (EPI) to determine the relationship between the effects of baroreflex activation and CA application on baroreceptive neurons in the vagal sensory nucleus Of 269 cells studied, 104 (38 7\%) exhıbited decreases and 41 cells $(152 \%)$ showed increases in firng rate in response to baroreflex activation, while the remaining 124 neurons showed no response All 3 CAs inhibited spike activity in the majority (68 5\%) of NTS cells These inhibitory effects on spontaneous firing were observed regardless of the response profile of a particular neuron to baroreflex activation The inhibitory effects of NE and EPI on NTS neuronal activity were specifically blocked by the $\alpha$-adrenergic receptor antagonist tolazoline, but not by the $\beta$-adrenergic antagonist sotalol These results indicate that CAs may interact at several sites within the NTS to influence baroreflex integration, and that the effects of NE and EPI on neuronal activity are mediated by an $\alpha$-adrenergic receptor
\end{abstract}

\section{INTRODUCTION}

The nucleus tractus solitaril (NTS), located in the dorsomedial medulla oblongata, is thought to play an important role in the mediation of the vagal baroreceptor reflex 5717 This cardiovascular reflex is activated by sudden increases in arterial blood pressure and brings about both a decrease in peripheral vascular resistance and negative chronotropic and inotropic effects on the heart ${ }^{13,25}$ This, in turn, leads to a drop in systemic blood pressure and a decrease in heart rate

Nerve fibers containıng norepinephrine (NE) and epinephrine (EPI) heavily innervate the NTS ${ }^{6,11,21}$ The greatest density of terminals which contain the catecholamines (CAs) are found at the level of the area postrema ${ }^{14}$ Electron microscopic studies in the rat have revealed that adrenergic nerve terminals in the NTS form synapses with dendrites, axons, and cell bodies ${ }^{2,26}$ While such anatomical results have been interpreted to favor the involvement of central CAs in autonomic regulation, the role played by this adrenergic input in the processing of baroreceptive information withın the NTS remains ill-defined Earlier studies performed in the rat have shown that microinjection of either NE or EPI into the nucleus precipitates a significant drop in blood pressure, thereby mimicking the effects of activation of the baroreflex $^{315}$ However, experiments involving injection of the catecholamine neurotoxin 6-hydroxydopamine into the NTS indicate that adrenergic afferents to the nucleus do not appear to be intrinsic to the circuitry of the baroreflex arc ${ }^{10,242728}$ Snyder et al ${ }^{24}$ and Talman et al ${ }^{27} 28$ have suggested that CAs may serve instead to modulate the activity of the baroreflex arc by facilitatıng the synaptic transmission of baroreceptive information from the primary baroreceptor afferents to the secondary baroreceptive neurons in the NTS

Clarification of adrenergic effects on synaptic 
transmission in the NTS can only proceed based upon firm knowledge of the specific nature and cellular sites of action of CAs within the nucleus Moore and Guyenet ${ }^{18}$ described the effects of iontophoretic application of adrenergic compounds on the spontaneous discharge of a subpopulation of noradrenergic cells within the commissural subnucleus of the NTS Their investigation revealed that the majority of the noradrenergic cells that sent projections rostrally through the medial forebrain bundle were inhibited by EPI acting via an $\alpha$-adrenergic receptor Conversely, Granata and Woodruff ${ }^{8}$ tound that the majority of cells in the NTS which responded to iontophoresis ot CAs were excited by NE One possible explanation for this discrepancy in results is that the two studies sampled different populations of neurons In this regard, Moore and Guyenet ${ }^{18}$ identitied the cells in their study on the basis of their efferent projections to the forebrain, whereas Granata and Woodruff ${ }^{8}$ made no attempt to characterize the cells in their study according to either hodology or physiology

The purpose of the present study was to characterize the responsiveness to CAs of cells in the caudal NTS that were specifically identified as baroreceptive in nature Neuronal responses to iontophoretic application of putative adrenergic neurotransmitters were examined in the absence and presence of specific adrenergic receptor antagonists and correlated with responses to activation of the baroreflex arc brought about by pharmacologically induced elevations of blood pressure The results indicate that CAs consistently decrease the spontaneous activity of baroreceptive neurons within the NTS independently of the responses of the neurons to blood pressure elevation, and that this effect is mediated by an $\alpha$-adrenergic receptor

\section{MATERIALS AND METHODS}

\section{Preparatory surgery}

Experiments were carned out on 49 male SpragueDawley rats (200-500 g) Each anımal was anesthetized with urethane $(15 \mathrm{~g} / \mathrm{kg}, 1 \mathrm{p})$ and the right femoral artery was cannulated to monitor blood pressure via a Gould Statham P23 Db pressure transducer Another catheter was placed in the right femoral vein tor infusion of the pressor substance, phenylephrne $\mathrm{HCl}(2-4 \mu \mathrm{g} / \mathrm{kg}, \mathrm{pH} 74)$ The anımal was then placed in a stereotaxic frame and prepared surgically tor electrophysiological recordıng The dorsal neck muscles were retracted and a partial occipital cranıotomy was performed The atlanto-occipital membrane and dura mater were excised, exposing the dorsal surface of the medulla, and a pressor toot was lowered to the brain surface to dampen the mechantcal vibrations set up by nearby blood vessels

\section{Electrophysiological recording and microlontophore- sis}

Five-barreled glass microelectrodes with 3-8- $\mu \mathrm{m}$ tıps were used to record extracellularly from single neurons in the NTS at the level of the area postrema and to apply drugs by microiontophoresis at the site of recording The center barrel was filled with a $2 \%$ solution (w/v) of Pontamıne sky blue dye in $05 \mathrm{M}$ sodium acetate and was used for recording cellular activity Recording barrel resistances typically ranged from 3 to $8 \mathrm{M} \Omega$ Three of the peripheral barrels were filled with various combinations of the following drugs L-epınephrıne (0 $2 \mathrm{M}, \mathrm{pH} 40$, Sigma), L-norepınephrıne $\mathrm{HCl}(02 \mathrm{M}, \mathrm{pH} 40$, Sıgma), dopamine $\mathrm{HCl}$ (0 $2 \mathrm{M}, \mathrm{pH} 40$, Sigma), $\gamma$-amınobutyric acıd (GABA, $01 \mathrm{M}, \mathrm{pH} 4$ 0, Sigma), tolazoline $\mathrm{HCl}(01$ $\mathrm{M}, \mathrm{pH} 40$, CIBA-Gergy), sotalol $\mathrm{HCl}(01 \mathrm{M}, \mathrm{pH}$ 40 , Bristol-Myers) Automatic current balancing was maintained through the remaining peripheral barrel, which was filled with $3 \mathrm{M} \mathrm{NaCl}$ Positive and negative currents were independently passed through this barrel to control for possible current artifacts that might have arisen during drug ejection Constancy of the amplitude of the extracellularly recorded action potentials was monitored throughout the course of each experıment to control for possible anesthetic effects of the ejected drugs or changes in the electrode-to-cell distance Drugs were ejected as cations using ejection currents of up to 150 $\mathrm{nA}$ and retained by application of 10-20 nA currents of opposite polarity

Action potentials of individual neurons were monitored on an oscilloscope and converted to umiform voltage pulses by a window discriminator (Labstar NSP-105) The pulses were integrated over 1- or 2-s intervals by a ratemeter and displayed on a stripchart recorder together with simultaneous blood pressure tracings Cells displaying rhythmic actıvity that appeared synchronous with respiratory movements 
were excluded from the analysis Testıng of neuronal responses to blood pressure elevation was performed 2-5 tımes in each cell studied, and activation of the baroreflex was verified by noting the increase in the cardiac interbeat interval

The window discriminator output was also led to a digital computer (S/120 Microeclipse, Data General) which summed unit actıvity durıng regularly spaced iontophoretic pulses of an agonist in the manner of a perievent histogram ${ }^{14}$ Responsiveness of each neuron to a CA was first determıned by applyıng the agonist at fixed intervals with electrophoretic pulses of uniform duration and incrementing the level of ejection current untıl a well-defined response became apparent To quantify neuronal responses to an agonist, the discharge rate during application of the agonist was compared with the rate between pulses, and the difference was expressed as a percentage of inhibition or excitation Discharge rates were calculated by the computer by dividing the number of counts in a given response period by the product of the duration of the period, in $s$, multiphed by the number of agonist pulse cycles The period of response to an agonist was selected to begin at the particular time bin where counts deviated significantly from baseline and to terminate at the bin where counts reapproached the baseline (Student's $t$-test) For the most part, all histograms for a particular cell were constructed with equal numbers of pulse cycles to facilitate companisons between histograms

Once the control response of a cell to a fixed level of CA was determined, iontophoresıs of an antagonist was begun and another histogram constructed to quantify any changes in the agonist-induced response All histograms were constructed when the level of background discharge was steady to avold artıfacts due to variations in neuronal activity during antagonist administration Blockade of agonist actıon durıng application of antagonıst was defined as a decrease in the agonist-induced response of at least $50 \%$ Additional histograms were constructed after termınation of antagonıst application to monitor the recovery of agonist-induced neuronal responses to control levels If recovery was not observed within 30 mın after termınation of antagonıst application, the cell was excluded from the analysis Each cell was typically monitored for at least $2 \mathrm{~h}$

\section{Histology}

Upon termination of each experiment, the pos1tıons of individual recording tracks were marked by passing $20 \mu \mathrm{A}$ of anionic current through the recording barrel for $15-20 \mathrm{~min}$, thereby depositing spots of Pontamıne blue dye at the electrode tıp Anımals were then perfused with an intracardiac infusion of a $10 \%$ solution $(\mathrm{w} / \mathrm{v})$ of buffered formalın phosphate The location of each recording track and sites of recorded neurons were verified histologically in 50$\mu \mathrm{m}$ frozen sections counterstained with Neutral red

\section{RESULTS}

Responses of neurons in the NTS to activation of the baroreceptor reflex

Two-hundred sixty-nine neurons located within the NTS were examined for their responses to transient elevations of arterial blood pressure These neurons typically exhibited randomized patterns of repetitive single-spike activity which bore no obvious relationship to spontaneous fluctuations in heart rate or restıng blood pressure Nearly one-half $(n=129)$ of the neurons sampled had basal firing frequencies between 5 and 12 spikes/s However, rates of sponta-

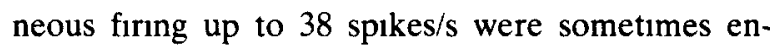
countered These findings are in keeping with the results of previous investigations in the rat ${ }^{18} 1920$

A neuron was classified as 'baroreceptive' if it displayed an increase or decrease of at least $30 \%$ in baselıne spike activity in response to transient elevation of blood pressure Such responses, as illustrated in Fig 1, were observed after infusion of the pressor substance in 145 of the 269 cells (54\%) Of the 145 baroreceptive cells, 104 displayed decreases in firing rate, whereas the remaining 41 showed increases in firıng rates No significant differences were seen in the mean rates of baselıne firıng between groups of cells categorized according to their response profiles to baroreflex activation ( $P>01$, Cochran's unpaired $t$-test)

Neurons responded to infusion of the pressor agent at latencies which ranged from less than $1 \mathrm{~s}$ up to $20 \mathrm{~s}$ In some cases $(n=58)$, cells responded shortly after blood pressure began to rise An example of this is shown in the cell depicted in Fig 1A This neuron responded in an excitatory manner to blood pressure elevation, with an onset of response occur- 
A
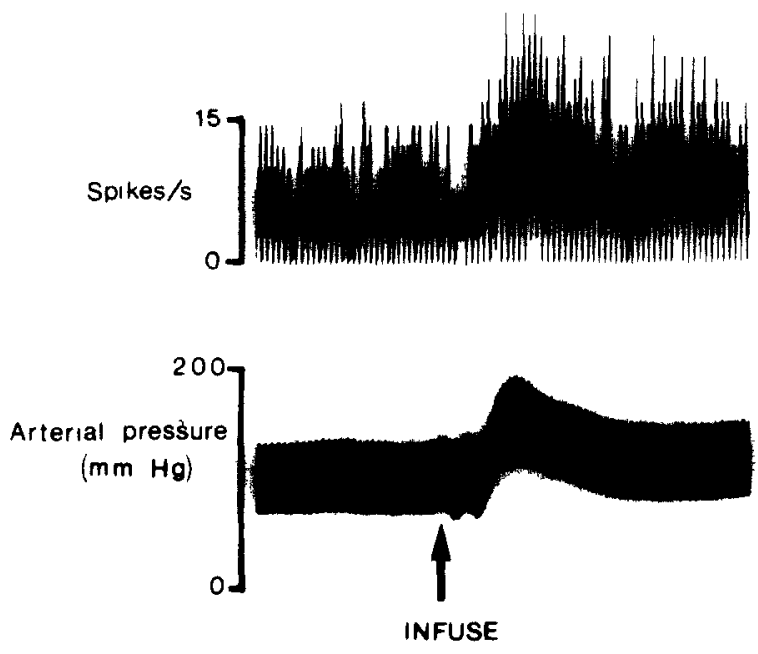

B.
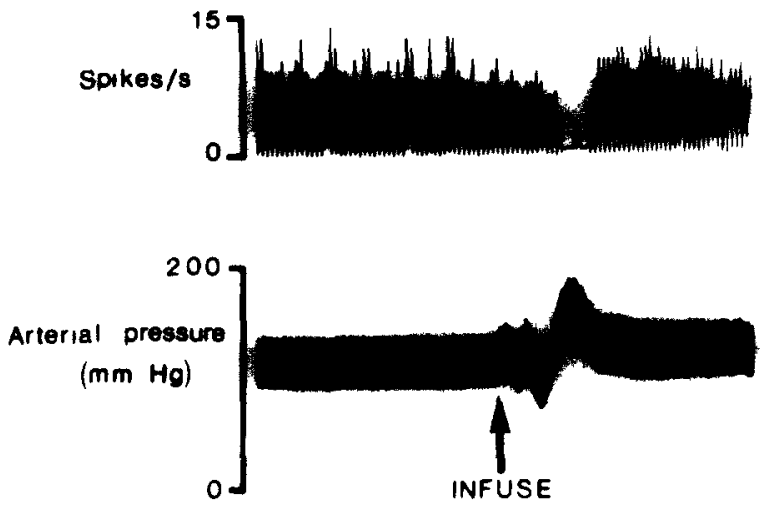

$15 \mathrm{~s}$

Fig 1 Effects of blood pressure elevation on the discharge rate of neurons in the NTS The top tracings in A and B are integrated ratemeter records of cell activity measured in spikes per second The bottom tracings in A and B show changes in arterlal blood pressure measured in $\mathrm{mm} \mathrm{Hg}$ and recorded simultaneously with cell activity $A$ excitatory response to elevation of blood pressure B inhibitory response to elevation of blood pressure Arrows indicate times of infusion of a bolus of pressor substance Time calibration is in $\mathrm{s}$

ring at an arterial pressure of $165 \mathrm{~mm} \mathrm{Hg}$ In other instances $(n=24)$, cells did not begin to show sıgnificant changes in firing rate untıl the peak in arterial pressure was reached For example, the neuron shown in Fig 1B responded to pressure elevation in an inhibitory manner with a response latency of $6 \mathrm{~s}$
The onset of its response occurred at a peak arterial pressure of $190 \mathrm{~mm} \mathrm{Hg}$ Cases $(n=11)$ were also sometımes encountered in which the change in tirıng rate of a cell did not occur until after the peak pressure had been reached and pressures began to return to baselıne Surprisingly, many cells $(n=52)$ displayed all 3 patterns of response, indicatıng that in general, neurons could not be reliably categonzed according to their response latencies to elevation of arterial pressure

Because of the close proximity of the NTS to the area postrema, a structure in which the blood-brain barrier is notably absent, it was important to determine whether some of the observed neuronal responses to phenylephrine infusion might be due to a direct action of the $\alpha$-adrenergic agonist on the recorded neurons, rather than to the effects of baroreflex activation To assess this possibility, 13 addıtional neurons were examıned for their responses to phenylephrine-induced elevations of blood pressure following bilateral transection of the vagus and glossopharyngeal nerves The patterns and rates of spontaneous activity (mean $=1354 \mathrm{spikes} / \mathrm{s}, \mathrm{S}$ E M $=134$ ) of these 13 cells did not appear to differ significantly from those of the 269 NTS neurons recorded in the intact anımal However, i v infusion of phenylephrine had no discernible effect on the activity of any of these 13 neurons, despite the fact that the doses of phenylephrine that were administered consistently produced elevations of blood pressure equal to or greater than those produced in the intact anımals These findings argue strongly that the changes in NTS neuronal activity elicited in the intact anımals by phenylephrıne-induced elevdtions of blood pressure resulted from the activation of baroreflex pathways, rather than an action of the $\alpha$-adrenergic agonist on the neurons under studv

\section{Anatomical distribution of baroreceptive neurons in the NTS}

Histological verification of the locations of the 269 neurons studied in the intact anımals revealed slight differences in the anatomical distributions of cells when grouped on the basis of their responses to baroreflex activation ( $\mathrm{Fig} 2$ ) Although cells that were inhibited by pressure elevation were encountered throughout the nucleus, these units were found in greatest abundance in the dorsal regions of the medial 
A INHIBITED CELLS

$N=104$

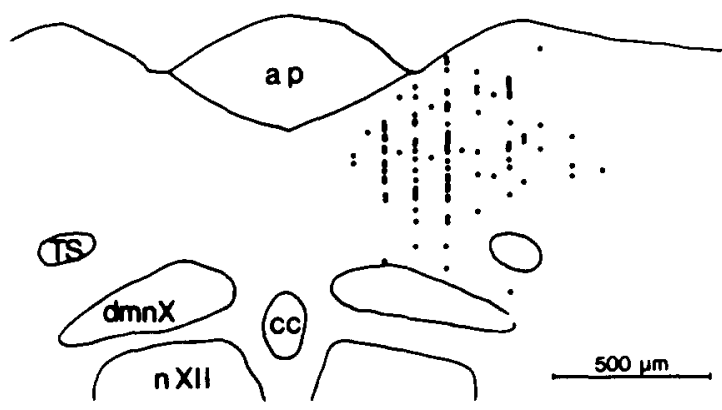

B EXCITED CELLS

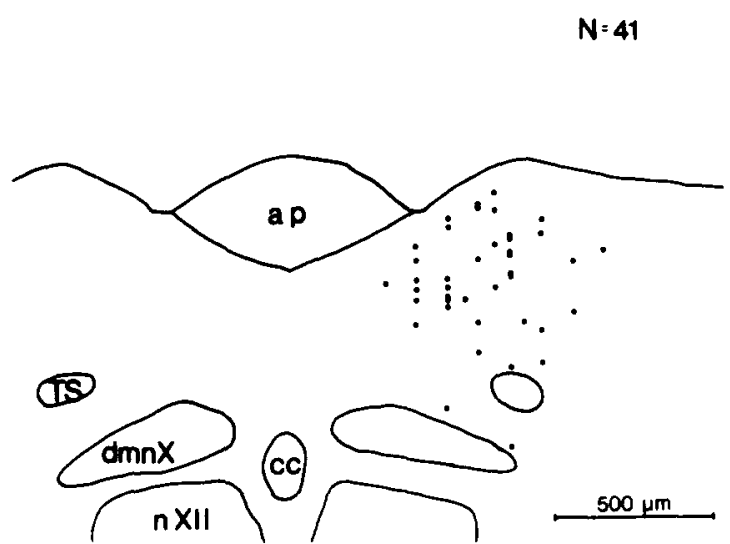

Fig 2 Anatomical distributions of NTS neurons displayıng inhibitory or excitatory responses to blood pressure elevation A distribution of inhibited neurons $B$ distribution of excited neurons ap, area postrema, cc, central canal, dmnX, dorsal motor nucleus of the vagus, nXII, hypoglossal nucleus, TS, solitary tract
NTS (Fig 2A) The greatest density of these units was observed ca $500 \mu \mathrm{m}$ lateral to the midline The distribution of cells that were excited by blood pressure elevations was shifted laterally with respect to that of the inhibited class of cells (Fig 2B) While also concentrated in the dorsal regions of the medial NTS, cells that were excited were more likely to be encountered between 500 and $800 \mu \mathrm{m}$ lateral to the midline, with the greatest density $700 \mu \mathrm{m}$ lateral to the midline Units that were unresponsive to elevations in blood pressure were found throughout the dorsomedial medulla

Responses of neurons in the NTS to microlontophoretic application of catecholamines

Two-hundred thirty-two of the 269 neurons stud1ed were examıned for their responses to contophoretıc administration of dopamine (DA), NE, or EPI (Table I) Of the 161 cells that responded to CA application, 159 (68 5\%) were inhibited by iontophoretic application of the biogenic amınes, whereas increases in firıng rate were observed in only two neurons $(1 \%)$ The responses of a cell tested with all 3 of the CAs is illustrated in Fig 3 As this figure shows, inhibitory responses to iontophoresis of the CAs were typically characterized by long latencies to onset and by relatively slow recoveries to baselıne levels of spike discharge All responses to CA iontophoresis were found to be reversible and graded in magnitude and duration in direct relation to the level of iontophoretic current used to eject the drugs As shown in Table I, $66 \%$ of the cells tested with EPI ( $n$ $=85), 73 \%$ of those tested with NE $(n=104)$, and $67 \%$ of those tested with DA $(n=26)$ were responsive to application of those CAs $\chi^{2}$-Tests revealed

\section{TABLE I}

\section{Responses of NTS neurons to elevation of blood pressure and microtontophorettc application of catecholamines}

In total, 232 neurons in the NTS were examined for their responses to elevation of blood pressure (b p ) and to microiontophoretic application of EPI. NE or dopamine The 39 cells tested with dopamine were also tested for their responsiveness to NE and EPI See text for discussion

\begin{tabular}{|c|c|c|c|c|}
\hline & Catec & $a d m i n$ & & \\
\hline & $\overline{E P I}$ & $\overline{N E}$ & Dopamine & Total cells \\
\hline Total cells studied & 128 & 143 & 39 & 232 \\
\hline CA-responsive cells & 85 & 104 & 26 & 161 \\
\hline CA-responsive cells inhibited by $b \mathrm{p}$ elevation & 30 & 43 & 11 & 62 \\
\hline CA-responsive cells excited by b p elevation & 15 & 21 & 4 & 31 \\
\hline $\mathrm{CA}$-responsive cells unresponsive to $\mathrm{b} p$ elevation & 40 & 40 & 11 & 68 \\
\hline
\end{tabular}


A

Dopamine 50 nA

- - - -

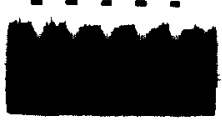

B

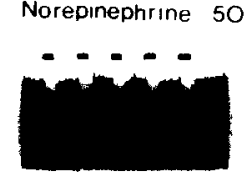

C Epinephrine 50nA
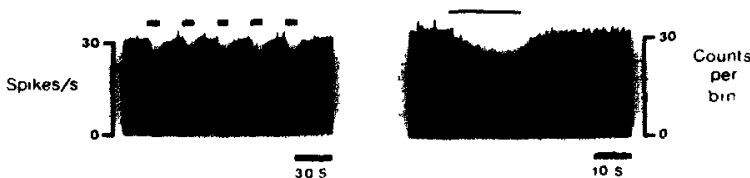

Fig 3 Responses of a single NTS neuron to microiontophoretic applications of dopamine (A), norepinephrine (B), and eplnephrne $(C)$ The tracings on the left are integrated ratemeter records of cell activity measured in spikes/s The tracings on the right are computer-generated histograms of the cellular activity displayed in the accompanying ratemeter records Each histogram shows cellular activity accumulated over 5 cycles of drug application and is measured in counts per 200-ms time bin Solid bars indicate periods of application of agonist

that the proportions of cells responding to each of the 3 CAs were not significantly different $(P>01)$ Comparison of the latencies and magnitudes of the responses to $\mathrm{CA}$ application revealed no significant differences between the effects of the three CAs on neuronal activity $(P>01$, one-way analysis of var1ance)

To determine whether the different classes of baroreceptive cells showed differential sensitivities to CA application, the $161 \mathrm{CA}$-responsive cells were grouped according to their response profiles to baroreflex activation and the particular CA being applied (Table I) Two-way analyses of variance of the latencles and magnitudes of the unit responses revealed that the CAs had similar inhibitory effects on the activity of NTS neurons $(P>01)$, regardless of the response profiles of the cells to baroreflex activation However, because over four-fifths $(n=193)$ of the 232 cells studied for their responsiveness to CA appl1cation were tested with only a single agonist, the possibility could not be excluded that the lack of correla- tion between blood pressure response piotıles and responsiveness to CAs might reflect a sampling bias owing to the restricted testing of adrenergic sensitivity This possibility was examined by comparing the responses of the remaining 39 neurons to application of all 3 of the CAs Of the 39 cells, $23(59 / \%)$ displayed decreases in spike dctivity durıng application of each of the agonists (Table II) Eleven cells were unresponsıve to any of the 3 CAs, while the remainIng 5 neurons were inhibited by either one or two of the CAs Significantly more neurons in the group of cells showing excitatory responses to blood pressure elevation were unresponsive to all 3 of the CAs, while the group of cells showing inhibitory responses to pressure elevation had a correspondingly higher proportion of units that were responsive to CA appl1cation $\left(P<005, \chi^{2}\right.$-test $)$

Histological reconstructions were made of the anatomical locations of cells responsive to the CAs and those cells showing no response to $\mathrm{CA}$ administration Both groups of neurons were randomly distributed throughout the NTS, with no restriction to any particular cytoarchitectonic structure

\section{Specificity of action of adrenergic agonists}

Neuronal responses to NE and EPI were exam-

\section{TABLE II}

Responsiveness of NTS neurons to microiontophorettc application of EPI, NE and dopamine

Each of 39 NTS cells was studied for its responsiveness to dopamine, NE, and EPI and to blood pressure (b p ) elevation All responses to the catecholamines (CAs) were found to be inhibltory Significantly more blood pressure-inhibited cells were responsive to application of at least one CA, while fewer pressure-excited cells were responsive to any CA $\left(P<005, \chi^{2}-\right.$ test)

\begin{tabular}{|c|c|c|c|}
\hline & \multicolumn{3}{|c|}{$\begin{array}{l}\text { Neuronal response to blood pressure } \\
\text { elevatton }\end{array}$} \\
\hline & $\begin{array}{l}\text { Inhibl- } \\
\text { tlon }\end{array}$ & $\begin{array}{l}\text { Exctta- } \\
\text { tion }\end{array}$ & $\begin{array}{l}\text { No } \\
\text { response }\end{array}$ \\
\hline $\begin{array}{l}\text { Cells studied } \\
\text { Cells responsive }\end{array}$ & 14 & 8 & 17 \\
\hline $\begin{array}{l}\text { to all } 3 \text { CAs } \\
\text { Cells responsive } \\
\text { to one or } \\
\text { two CAs }\end{array}$ & 9 & 3 & 11 \\
\hline $\begin{array}{l}\text { Cells unrespon- } \\
\text { sive to any of } \\
\text { the CAs }\end{array}$ & 3 & 3 & 5 \\
\hline
\end{tabular}


ined in the absence and presence of the $\alpha$-adrenergic receptor antagonist tolazoline and of the $\beta$-antagonist sotalol to classify the receptors mediatıng the inhibitory actions of these putative adrenergic neurotransmitters in the NTS The results of such an experiment on one NTS neuron are illustrated in Fig 4 The control response of this cell to iontophoresis of NE $100 \mathrm{nA}$ (solid bars) was characterized by a decrease in firıng rate of $69 \%$ (Fig 4A) The reduction in spike activity induced by NE was essentially abolished in the presence of a $40 \mathrm{nA}$ application of tolazoline (dotted bars, Fig 4B) The inhibitory response to NE returned to control levels within $15 \mathrm{~min}$ following termınation of administration of tolazolıne (Fig 4C) In contrast to the effects of tolazoline, ap-

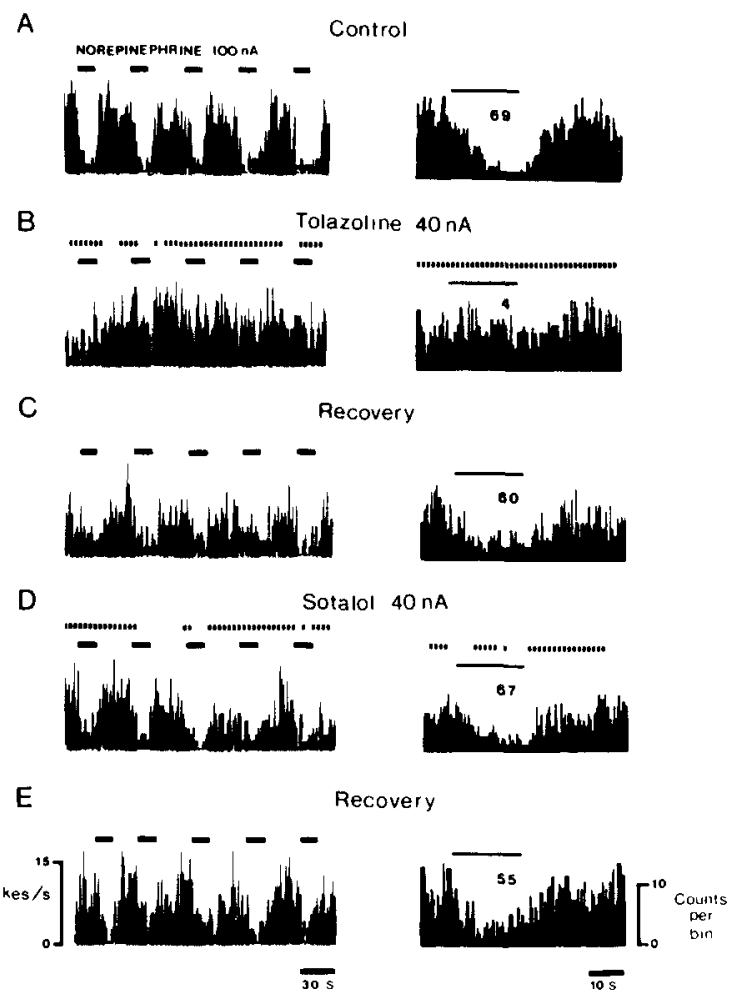

Fig 4 Blockade of neuronal responses to NE by tolazolıne but not by sotalol The ratemeter records on the left show the response of an NTS neuron to $100 \mathrm{nA}$ applications of NE (solid bars) delivered before, during and after an continuous 40-nA application of either tolazoline or sotalol (dotted line) Corresponding computer-generated histograms (right) show cellular actıvity accumulated over 5 cycles of drug application and measured in counts per $200 \mathrm{~ms}$ time bin Continuous application of tolazoline blocked the inhibitory responses to NE (B) Following the recovery of NE-induced inhibition to control levels $(\mathrm{C})$, sotalol was administered but faled to block the inhibitory responses to NE (D)
TABLE III

Blockade of neuronal responses to NE or EPI by tolazoline and sotalol

Responses of NTS neurons to microiontophoretic application of NE ( $n=16$ cells) or EPI $(n=16$ cells) were examined in the absence and presence of tolazoline and sotalol Inhibitions in firıng produced by either agonıst were preferentially blocked by the $\alpha$-adrenergic antagonist but not the $\beta$-adrenergic antagonist

\begin{tabular}{|c|c|c|c|}
\hline & \multicolumn{3}{|c|}{$\begin{array}{l}\text { Neuronal response to elevation of } \\
\text { blood pressure }\end{array}$} \\
\hline & $\begin{array}{l}\text { Inhibl- } \\
\text { tlon }\end{array}$ & $\begin{array}{l}\text { Excita- } \\
\text { thon }\end{array}$ & $\begin{array}{l}\text { No } \\
\text { response }\end{array}$ \\
\hline $\begin{array}{l}\text { Cells responsive } \\
\text { to } \mathrm{NE}\end{array}$ & 7 & 3 & 6 \\
\hline $\begin{array}{c}\text { Blockade of } \mathrm{NE} \\
\text { response by } \\
\text { tolazoline }\end{array}$ & 6 & 3 & 4 \\
\hline $\begin{array}{l}\text { Blockade of } \mathrm{NE} \\
\text { response by } \\
\text { sotalol }\end{array}$ & 0 & 0 & 0 \\
\hline $\begin{array}{l}\text { Cells responsive } \\
\text { to EPI }\end{array}$ & 5 & 3 & 8 \\
\hline $\begin{array}{l}\text { Blockade of } \\
\text { EPI response } \\
\text { by tolazoline }\end{array}$ & 3 & 3 & 7 \\
\hline $\begin{array}{l}\text { Blockade of } \\
\text { EPI response } \\
\text { by sotalol }\end{array}$ & 0 & 0 & 0 \\
\hline
\end{tabular}

plication of sotalol $40 \mathrm{nA}$ (dotted bars, Fig 4D) failed to diminish the inhibitory effects of NE, even when the $\beta$-adrenergic antagonist was applied at microiontophoretic doses producing a direct suppression of baseline discharge (Fig 4D)

The effects of NE were tested in this manner in 16 NTS neurons (Table III) Inhibitory responses to NE were antagonized by tolazoline in 13 cells In comparison, sotalol had no effect on the neuronal responses to NE, even when administered at iontophoretic doses that exerted direct suppression of both action potentıal amplitudes and baselıne firıng Specific blockade of NE responses by the $\alpha$-antagonist was observed in neurons located throughout the NTS and was independent of the response profile of a given cell to blood pressure manipulation

The inhibitory responses of NTS cells to EPI were similarly blocked by iontophoretic administration of $\alpha$-but not $\beta$-adrenergic antagonısts $F_{1 g} 5$ shows the results of a typical experiment in which the ability of tolazoline and sotalol to block EPI-induced inhibitions in firıng was examıned in the same NTS 
A

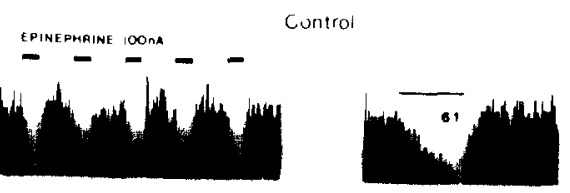

B
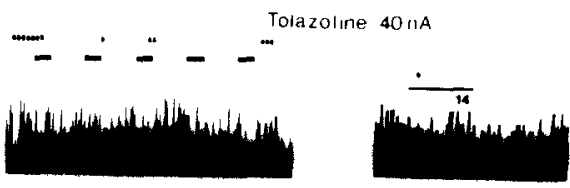

$\mathrm{C}$

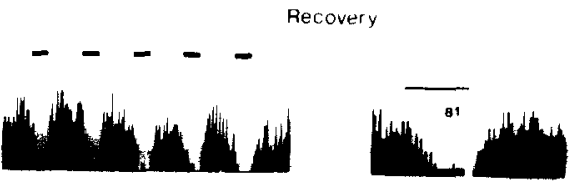

D

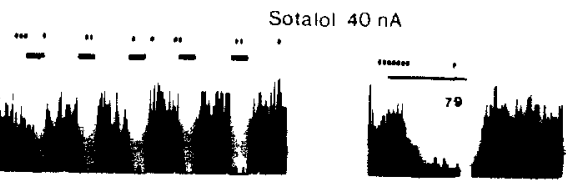

E

Recovery
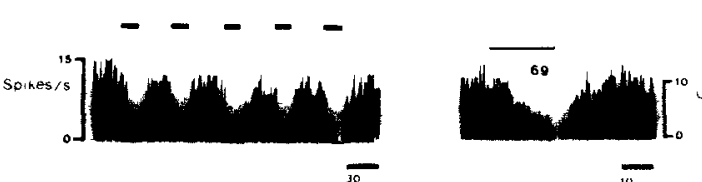

Fig 5 Blockade of neuronal responses to EPI by tolazolıne but not by sotalol The ratemeter records (left) show the response of an NTS neuron to application of EPI $100 \mathrm{nA}$ (solid bars) delivered before, durıng, and after a contınuous $40-\mathrm{nA}$ application of either tolazolıne or sotalol (dotted bars) Histogram records at the right correspond to the cellular activity displayed in the accompanying ratemeter records Each histogram shows cellular activity accumulated over 5 cycles of drug application and is measured in counts per 200-ms tıme bin Contınuous application of tolazoline blocked the inhibitory responses to EPI (B) Following the recovery of EPI-induced inhibition to control levels $(C)$, sotalol was administered but fatled to block the inhibitory responses to EPI (D)

neuron In this cell, the control response to iontophoresis of EPI $100 \mathrm{nA}$ (solid bars) was characterized by a decrease in firing rate of $61 \%$ (Fig 5A) Application of tolazoline $40 \mathrm{nA}$ (dotted bars, Fig 5B) abolıshed the inhibitory effect of EPI on spike actıvity Termınation of tolazolıne application was accompanied by a return of EPI-induced responses to control levels ( $\mathrm{F}_{1 \mathrm{~g}}$ 5C) As was the case with NE-induced inhibitions of firing, administration of sotalol $40 \mathrm{nA}$ (dotted bars, Fig 5D) falled to block inhibitory responses to EPI

Mediation of the effects of EPI by an adrenergic receptor was investigated in this manner in 16 cells
(Table III) Tolazoline blocked the inhibitory action of the adrenergic agonist in 12 of the 16 neurons Sotalol had no appreciable effect on EPI-Induced inhibıtıons in firıng, even when administered at iontophoretic doses exerting strong suppression of baseline spike activity

\section{Specificity of adrenergic antagonists}

Speciticity of the action of adrenergic antagonists against NE- and EPI-1nduced inhibitions in firıng was further assessed by examıning the ability of the antagonists to block neuronal inhibitions produced by a non-adrenergic agonist, GABA The effects of tontophoretic admınıstration of tolazoline or sotalol on inhibitory responses to NE and GABA were examined, respectively, in an additional 25 and 24 of the 104 neurons that had been initially characterized as responsive to NE (Table IV) NE-induced inhibitions were blocked by tolazoline in 20 of the 25 cells tested, whereas inhibitory responses to GABA in the same cells were blocked in only one case Sotalol blocked NE-induced inhibitions in firing in only 3 of the 24 cells tested, while the inhibitory effect of GABA was not altered by administration of the $\beta$-adrenergic antagonist in any of the neurons

In similar types of experiments, the etfects of tolazoline or sotalol on the inhibitory responses to EPI and GABA were each compared in an additional 17 cells selected from the 85 cells found to be responsive to EPI (Table IV) Administration of tolazolıne resulted in specific blockade of inhibitory responses to EPI in 15 of 17 cells tested without affectıng GABAinduced inhibitions in firing In contrast, inhibitory responses to EPI or GABA were not blocked by administration of sotalol in any of the 17 additional cells tested with the $\beta$-adrenergic antagonist

\section{DISCUSSION}

Several earlier studies in the cat and dog have reported the presence of cells in the dorsomedial medulla which increase ${ }^{1623}$ or decrease ${ }^{162223}$ their rates of firing in response to arterial pressure elevation Moore and Guyenet ${ }^{19,20}$ have reported the presence of cells in the rat NTS which also display inhibitory responses to blood pressure elevation However these investigators did not encounter units displaying excitatory responses to increases in blood pressure 
TABLE IV

Blockade of neuronal responses to adrenergic agonists and GABA by tolazoline or sotalol

The responses to NTS neurons to microıontophoretıc application of catecholamines (CAs) and GABA were examıned in the absence and presence of tolazoline or sotalol The $\alpha$-adrenergic antagonist preferentially blocked inhibitory responses to NE and EPI but had little effect on inhibitory responses to GABA The $\beta$-adrenergic antagonist falled to block neuronal responses to any of the agonists

\begin{tabular}{|c|c|c|c|c|c|}
\hline \multirow{2}{*}{$\begin{array}{l}\text { Agonist } \\
\text { tested }\end{array}$} & \multirow{2}{*}{$\begin{array}{l}\text { Antagontst } \\
\text { tested }\end{array}$} & \multirow{2}{*}{$\begin{array}{l}\text { Neuronal response } \\
\text { to elevatton of } \\
\text { blood pressure }\end{array}$} & \multirow{2}{*}{$\begin{array}{l}\text { Number of cells } \\
\text { responding to } \\
C A \text { and } G A B A\end{array}$} & \multicolumn{2}{|c|}{ Blockade by antagontst } \\
\hline & & & & $\begin{array}{l}\text { CA-induced } \\
\text { inhibition }\end{array}$ & $\begin{array}{l}\text { GABA-tnduced } \\
\text { thhibitton }\end{array}$ \\
\hline \multirow[t]{6}{*}{$\mathrm{NE}$} & Tolazolıne & Inhibition & 7 & 7 & 1 \\
\hline & $n=25$ & Excitation & 6 & 5 & 0 \\
\hline & & No response & 12 & 8 & 0 \\
\hline & Sotalol & Inhibition & 11 & 1 & 0 \\
\hline & $n=24$ & Excitation & 4 & 1 & 0 \\
\hline & & No response & 9 & 1 & 0 \\
\hline \multirow[t]{6}{*}{ EPI } & Tolazolıne & Inhibition & 5 & 5 & 0 \\
\hline & $n=17$ & Excitation & 5 & 5 & 0 \\
\hline & & No response & 7 & 5 & 0 \\
\hline & Sotalol & Inhibition & 7 & 0 & 0 \\
\hline & $n=17$ & Excitation & 4 & 0 & 0 \\
\hline & & No response & 6 & 0 & 0 \\
\hline
\end{tabular}

The present investigation confirms and extends these earlier observations in presenting evidence for the existence of cells in the NTS of the rat which are excited as well as those which are inhibited by baroreflex activation The difference between our results and those obtained by Moore and Guyenet ${ }^{20}$ may be due in part to differences in sampling methods, as their observations were restricted to cells in the A2noradrenergic region of the NTS that could be ant1dromically actıvated by electrical stımulation of the medial forebrain bundle Salmoiraghi ${ }^{23}$ reported that cells in the feline NTS that are inhibited by blood pressure elevation outnumber those cells that are excited by a margin of 91 While our data indicate only a 21 ratio between baroreflex-inhibited and -excited cells in the rat NTS, it is apparent that the predominant response of baroreceptive neurons to blood pressure elevation was a depression of spontaneous firıng rate

Although the anatomical distributions of the two populations of baroreceptive cells found here in the rat NTS overlapped to a large extent, the center of the distribution of cells excited by baroreflex activation was lateral to that of the inhibited cells This difference in distributions cannot simply be explained in terms of the classically defined cytoarchitectonic boundaries $^{12}$, since both types of baroreceptive cells were found in similar subdivisions of the NTS Nevertheless, the possibility exists that such a difference in the anatomical distributions of the two populations of cells might reflect a difference in the physiological function of the two cell types In this regard, Laubie and Schmitt ${ }^{16}$ have presented evidence which suggests that single units in the canıne NTS that are inhibited by blood pressure elevation may be considered as 'sympathoexcitatory or vagoinhibitory', while those units that are excited by pressure elevation may be considered as 'sympathoinhibitory or vagoexcitatory'

To date, little attention has been focused on the effects of iontophoretic administration of CAs on the ongoing neuronal activity of single cells in the NTS Granata and Woodruff ${ }^{8}$ have reported predomınantly excitatory effects of both DA and NE on extracellularly recorded cells in the commissural subnucleus of the NTS Moore and Guyenet ${ }^{19}$, on the other hand, reported that iontophoretic administration of the $\alpha$-adrenergic agonists clonidine and EPI has an inhibitory effect on the ongoing spike activity of rostrally projectıng cells in the A2-region of the NTS Our own observations of the effects of iontophoresis of EPI on single-unit activity in the NTS support those of Moore and Guyenet ${ }^{19}$ However, in contrast with the findings of Granata and Woodruff ${ }^{8}$, we 
found that both DA and NE also had inhibitory effects on single-unit spike dctivity Although we are unable to account for the difference between our results and those obtained by Granata and Woodruff, it is unlikely that this variance in results was due to differences in the populations of NTS cells that were sampled, since in the present study inhibitory responses to CA application were found in essentially all cells throughout the caudal NTS that were studled It should be noted that inhibitory responses to the 3 CAs were seen in roughly two-thirds of all NTS cells, regardless of their response profiles to baroreflex activation Moreover, the majority of cells that responded to $\mathrm{CA}$ iontophoresis responded equally to all 3 of the CAs

The majority of studies aimed at elucidating the role of the CAs in baroreflex mechanisms have utılized microinjection techniques to deliver $\mu$ l quantıties of adrenergic agents into the NTS while monitoring the resultant changes in heart rate and blood pressure These studies have for the most part reported that microinjection of EPI. NE, or DA into the caudal NTS evokes a rapid and dose-dependent drop in blood pressure ${ }^{39,15}$ These kinds of data have been interpreted to suggest that CAs act in the NTS in such a way as to stimulate or facilitate the baroreflex Lending support to this idea is the electrophysiological work of Moore and Guyenet ${ }^{19} 211$ who found that single units of the A2-noradrenergic cell group in rat NTS decrease their rates of firıng following either elevation of blood pressure or iontophoretic apphcation of the adrenergic agonists EPI and clonidine This similarity in effects was also seen in the majority of baroreceptive neurons in the present study Nevertheless, the finding here that iontophoretically applied EPI, NE, and DA have potent inhibitory effects on baroreceptive neurons in the NTS that are excited, in addition to those which are inhibited, by elevations in blood pressure suggests that CAs might play a more complex role in the processing of baroreceptive information in the NTS than has been previously surmised It is also apparent that clarification of the role of the CAs in the processing of baroreflex information will require a better understanding of the involvement of these two neuronal subtypes in nor- mal baroreceptive mechanısms

For the most part, previous attempts to classity the receptors that mediate CA actions in the NTS have also involved the use of the microinjection technique These studies have shown that the drop in blood pressure associated with microinjection of the CAs into the NTS can be prevented by prior microinjection into the nucleus of $\alpha$-adrenergic antagonısts such as phentolamine ${ }^{314}$ and piperoxane ${ }^{9}$ Electrophysiological studies carried out by Moore and Guyenet ${ }^{19}$ at the level of the single cell provide further support for the mediation of CA action in the NTS by an $\alpha$-adrenergic receptor These workers found that the inhibitory effect of iontophoretically applied EPI on the activity of rostrally projecting A2-cells could be prevented by concurrent iontophoresis of the $\alpha_{2}$ receptor antagonist piperoxane, but not of the $\beta$ adrenergic antagonist sotalol The present investigation confirms and extends these observations by demonstrating that the inhibitory effects of NE and EPI on baroreceptive neurons in the NTS can be prevented by the action of adrenergic antagonists selective for $\alpha$-but not $\beta$-adrenergic receptors Our results demonstrate further that the actions of both NE and EPI on baroreceptive cells in the rat NTS appear to be medıated by an $\alpha$-adrenergic receptor regardless of the response profiles of those cells to baroreflex activation Studies are presently under way in this laboratory to characterize the subclass of $\alpha$-adrenergic receptor that mediates the effects of CAs on baroreceptive neurons in the NTS

\section{ACKNOWLEDGEMENTS}

The authors are grateful to the following pharmaceutical companies for their generous gifts of adrenergic drugs Burroughs Wellcome, Ciba-Gergy, Mead Johnson and Co, and Pfizer This study was supported by USPHS Grant DA- 03365 and by a research career development award from The Chicago Community Trust/Searle Scholars Program to HCM This work was submitted by PDF in partial fulfillment of the requirements for the degree of Doctor of Philosophy in Neurosciences at The University of Michigan 


\section{REFERENCES}

1 Bloom, F E , Siggins, G R and Henriksen, S J , Electrophysiologic assessment of receptor changes following chronc drug treatment. Fed Proc Fed Am Soc Exp Blol , 40 (1981) 166-172

2 Chıba, $T$ and Kato, $N$, Catecholamınergic axo-axonıc synapses in the nucleus of the tractus solitarius (pars commissuralis) of the cat possible relation to presynaptic regulation of baroreceptor reflexes, Brain Research, 102 (1978) 255-265

3 DeJong, $W$ and Petty, $M$, Chemical stimulation of the nucleus of the solitary tract and the resultıng blood pressure response J Cardiovase Pharmacol, 4, Suppl 1 (1982) $577-580$

4 Freedman, R , Hoffer, B J and Woodward, D J , A quantitative microiontophoretic analysis of the responses of central neurones to noradrenaline interactions with cobalt, manganese, verapamil and dichloroisoprenaline, $\mathrm{Br} J$ Pharmacol , 54 (1975) 529-539

5 Fussey, I F , Kidd, C and Whitwam, J G , Single unit activity associated with cardiovascular events in the brainstem of the dog, $J$ Physiol (London), 191 (1967) 57P-58P

6 Fuxe, $\mathrm{K}$, The distribution of monoamine terminals in the central nervous system, Acta Physiol Scand, 64, Suppl 247 (1965) 38-85

7 Gabriel, $M$ and Seller, $H$, Interaction of baroreceptor afferents from carotid sinus and aorta at the nucleus tractus solitarı Pflugers Arch, 318 (1970) 7-20

8 Granata, A R and Woodruff, G N , Dopaminergic mechanisms in the nucleus tractus solitarius and effects on blood pressure, Brain Res Bull, 8 (1982) 483-488

9 Gurtu, S , Sinha, J N and Bhargava, K P , Involvement of alpha-2-adrenoreceptors of nucleus tractus solitarius in baroreflex mediated bradycardia, Naunyn-Schmiedeberg's Arch Pharmacol, 321 (1982) 38-43

10 Healy, D P , Jew, J Y, Black, A C and Willams, T H, Bradycardia following injection of 6-hydroxydopamine into the intermediate portion of the nucleus tractus solitarius medialis, Brain Research, 206 (1981) 415-420

11 Hokfelt, T , Fuxe, K, Goldstein, $M$ and Johansson, $\mathrm{O}$, Evidence for adrenaline neurons in the rat brain Acta Physiol Scand, 89 (1973) 286-288

12 Kalıa, $M$ and Sullıvan, J M , Braınstem projections of sensory and motor components of the vagus nerve in the rat, $J$ Comp Neurol, 211 (1982) 248-264

13 Kitamura, Y, Ishise, S , Pegram, B L, Kawamura, H and Frohlich, E D . Hemodynamic responses to bilateral lesions of the nucleus tractus solitarn in spontaneously hypertensıve and normotensive rats, Hypertension, 3 (1981) 362-366

14 Koda, L Y and Bloom, F E, Distribution of catecholamine-containing cell bodies and blood vessels in the rat nucleus tractus solitarius, Brain Research, 289 (1983) 71-78
15 Kubo, T and Misu, Y, Pharmacological characterization of the alpha-adrenoceptors responsible for a decrease in blood pressure in the nucleus tractus solitari of the rat, Naunyn-Schmedeberg's Arch Pharmacal, 317 (1981) $120-125$

16 Laubie, $M$ and Schmitt, $H$, Action of the morphınomimet1c agent, fentanyl, on the nucleus tractus solitaril and the nucleus ambiguus cardiovascular neurons, Eur $J$ Pharmacol , 67 (1980) 403-412

17 Lindgren, P and Uvnas, B , Postulated vasodilator center in the medulla oblongata, Am J Phystol, 176 (1954) $68-76$

18 Moore, S D and Guyenet, P G , An electrophysıological study of the forebrain projection of nucleus commissuralis prelımınary identıfication of presumed A2 noradrenergic neurons, Brain Research, 263 (1983) 211-222

19 Moore, S D and Guyenet, P G , Alpha-receptor mediated inhibition of A2 noradrenergic neurons, Brain Research, 276 (1983) 188-191

20 Moore, S D and Guyenet, P G , Effect of blood pressure on A2 noradrenergic neurons, Brain Research, 338 (1985) 169-172

21 Palkovits, $M$ and Jacobowitz, D M , Topographic atlas of catecholamine and acetylcholınesterase-containıng neurons in the rat brain II Hindbrain (mesencephalon, rhombencephalon), J Comp Neurol, 157 (1974) 29-42

22 Przybyla, A C and Wang, S C, Neurophysiological characteristics of cardiovascular neurons in the medulla oblongata of the cat, $J$ Neurophysiol , 30 (1967) 645-660

23 Salmoiraghı, G C , 'Cardiovascular' neurones in the brain stem of cat, J Neurophysiol, 25 (1962) 182-197

24 Snyder, D W, Nathan, M A and Reis, D J , Chronic lability of arterial pressure produced by selective destruction of the catecholamine innervation of the nucleus tractus solitaril in the rat, Circ Res , 43 (1978) 662-671

25 Stuesse, S L, Wallick, D W and Levy, M N , Autonomic control of right atrial contractile strength in the dog, Am J Physiol , 236 (1979) H860-H865

26 Takahashı, Y, Tohyama, M, Satoh, K, Sakumoto, T, Kashıba, A and Shimizu, N , Fine structure of noradrenaline nerve terminals in the dorsomedial portion of the nucleus tractus solitariı as demonstrated by a modified potassum permanganate method J Comp Neurol, 189 (1980) 525-535

27 Talman, W T , Alonso, D R and Ress, D J , Impairment of baroreceptor function and chronic lability of arterial pressure produced by lesions of A2 catecholamine neurons of rat brain failure to evolve into hypertension In $\mathrm{P}$ Sleight (Ed), Arterial Baroreceptors and Hypertension, Oxford University Press, Oxford, 1980, pp 448-454

28 Talman, W T , Snyder, D W and Reis, D J , Chronic lability of arterial pressure produced by destruction of A2 catecholaminergic neurons in rat brainstem, Circ Res, 46 (1980) 842-853 